Int. J. Electrochem. Sci., 1(2006)17-31

International Journal of

ELECTROCHEMICAL

SCIENCE

www.electrochemsci.org

\title{
Effect of Addition of Sulphide Ions on the Electrochemical Behaviour and Corrosion of Cu-Ag Alloys in Alkaline Solutions
}

\author{
Ayman M. Zaky ${ }^{*}$, Sayed S. Abd El-Rehim ${ }^{2}$ and Basheer M. Mohamed ${ }^{3}$ \\ ${ }^{1}$ Chemistry Department, Faculty of Science, South Valley University, Qena 83523, Egypt \\ ${ }^{2}$ Chemistry Department, Faculty of Science, Ain Shams University, Abassia, Cairo, Egypt \\ ${ }^{3}$ Egyptian Collaborative Oil Society \\ *E-mail: azaky1@yahoo.com
}

Received: 22 February 2006 / Accepted: 16 April 2006 / Published: 20 April 2006

The electrochemical behaviour of copper-silver alloys was studied in $0.5 \mathrm{M} \mathrm{NaOH}$ containing sulphide ions using cyclic voltammetric and potentiodynamic anodic polarization techniques between the hydrogen and the oxygen evolution reactions under the effect of different variables such as reversal potential, scan rate, sulphide ion concentration, temperature and number of repeated cycles. The anodic sweep of potential was characterized by the appearance of three potential regions: sulphide attack potential region, copper dissolution potential region and silver dissolution potential region, prior to the oxygen evolution reaction. The first potential region was characterized by the appearance of three anodic peaks $A_{1}, A_{2}$ and $A_{3}$, which were related to the formation of $\mathrm{Cu}_{\mathrm{x}} \mathrm{S}, \mathrm{Ag}_{2} \mathrm{~S}$ and sulphur on the electrode surface. The formation of $\mathrm{Cu}_{\mathrm{x}} \mathrm{S}$ and $\mathrm{Ag}_{2} \mathrm{~S}$ was associated with the formation of pits on the electrode surface. Scanning electron microscope was used to examine the electrode surface for pitting corrosion. In the copper dissolution potential region, copper dissolved selectively that was associated with the appearance of three anodic peaks $\mathrm{A}_{4}, \mathrm{~A}_{5}$ and $\mathrm{A}_{6}$, which are related to the formation of $\mathrm{Cu}_{2} \mathrm{O}$, $\mathrm{Cu}(\mathrm{OH})_{2}$ and $\mathrm{CuO}$, respectively. In the third potential region, silver dissolves, which was associated with the appearance of two anodic peaks $\mathrm{A}_{8}$ and $\mathrm{A}_{9}$, which were related to the formation of $\mathrm{Ag}_{2} \mathrm{O}$ and both of $\mathrm{Ag}_{2} \mathrm{O}_{2}$ and soluble $\mathrm{SO}_{4}{ }^{2-}$ compounds, respectively. X-ray diffraction analysis confirmed the existence of $\mathrm{Ag}_{2} \mathrm{~S}, \mathrm{Cu}_{\mathrm{x}} \mathrm{S}, \mathrm{Ag}_{2} \mathrm{O}$ and $\mathrm{CuO}$ on alloy I potentiodynamically polarized to $400 \mathrm{mV}$. The reverse sweep was characterized by the appearance of one activation peak $\mathrm{A}_{10}$ and eight cathodic peaks $\mathrm{C}_{1}, \mathrm{C}_{2}, \mathrm{C}_{3}, \mathrm{C}_{4}, \mathrm{C}_{5}, \mathrm{C}_{6}, \mathrm{C}_{8}$, and $\mathrm{C}_{9}$.

Keywords: $\mathrm{Cu}-\mathrm{Ag}$ alloys, sulphide, pitting corrosion, cyclic voltammetry, potentiodynamic.

\section{INTRODUCTION}

Copper-silver alloys have higher electrical and thermal conductivity compared to those of pure copper or pure silver. These properties extend the application of coatings containing silver to low power circuits used in electronics. Alloying with copper conserves silver and reduces costs [1]. In our 
previous study [2] the cyclic voltammetric curves of two $(\mathrm{Cu}-20 \% \mathrm{Ag})$ and $(\mathrm{Cu}-80 \% \mathrm{Ag})$ binary alloys were recorded between hydrogen and oxygen evolution reactions potentials in $\mathrm{NaOH}$ solutions at $25^{\circ} \mathrm{C}$. The voltammograms of these alloys reveal complex characters. Below certain critical anodic potentials $\mathrm{Cu}$, the less noble component dissolves preferentially and the voltammograms exhibit three anodic peaks and three cathodic peaks corresponding to the formation and reduction of $\mathrm{Cu}_{2} \mathrm{O}, \mathrm{Cu}(\mathrm{OH})_{2}$ and $\mathrm{CuO}$. Beyond the critical potentials, $\mathrm{Ag}$ starts to dissolve and the cyclic voltammogram shows further three anodic peaks and three cathodic peaks corresponding to the formation and reduction of $\mathrm{AgO}, \mathrm{Ag}_{2} \mathrm{O}$ and $\mathrm{Ag}_{2} \mathrm{O}_{2}$. Grazing angle x-ray diffraction on surface products at different anodic potentials confirmed these results. In the present work we extend the study to involve the effect of addition of sulphide ions on the corrosion of these alloys in alkaline medium. Scanning electron microscope was used to monitor pitting corrosion due to the addition of sulphide ions and also the formation of sulphur on the electrode surface. X-ray diffraction analysis was used to determine the composition of the corrosion products on the electrode surface.

\section{EXPERIMENTAL PART}

Pure $\mathrm{Cu}$ and $\mathrm{Ag}$ (supplied by Merck $99.99 \%$ ), and two $\mathrm{Cu}-\mathrm{Ag}$ alloys, one containing $20 \%$ by weight $\mathrm{Ag}$ (alloy I) and the other containing $80 \%$ by weight Ag (alloy II) were used as working electrodes. The two alloys were prepared by fusion of pure $\mathrm{Cu}$ and $\mathrm{Ag}$ constituents in a graphite crucible. The constitution of the two alloys was determined using x-ray fluorescence analysis. All the electrodes used were rods of cross sectional area $0.5 \mathrm{~cm}^{2}$ mounted in Teflon so that only the cross sectional area was in contact with the solution. Before each experiment, the electrode was polished with successively polishing emery papers followed with alumina paste in order to get a mirror like surface. The polished electrode surface was washed with doubly distilled water and degreased with acetone. A conventional electrochemical cell of $200 \mathrm{ml}$ capacity was used in the present work. It contained three separate compartments of which two were used for fitting the working and the counter electrodes, respectively. The third compartment was used for fitting the reference electrode, which was a saturated calomel electrode (SCE). The counter electrode was a graphite rod of large surface area $\left(10 \mathrm{~cm}^{2}\right)$. The solutions used were prepared from AnalaR grade chemicals and used without further purification. All experiments were performed using freshly prepared solutions and freshly polished electrodes. The electrochemical experiments were conducted using an EG\&G Galvanostat/Potentiostat Model 273A connected to a PII PC computer that used M352 SoftCorr II program. The base line for measuring the peak current density of the anodic peaks is 0.0 value. Surface morphology of the alloy I polarized to more noble potentials was obtained using scanning electron microscopy (SEM), model XL-200 Philips operated at $20 \mathrm{keV}$. The existence of sulphur on the electrode surface was proven using Energy dispersive spectroscopy (EDS) analysis equipped in the scanning electron microscopy (SEM) set. The composition of the corrosion products formed during anodic polarization over the electrode surface was examined by means of x-ray diffraction analysis using Philips P. W. Model 1730 diffractometer adopted at $40 \mathrm{kV}$ and $25 \mathrm{~mA}$ with $\mathrm{Cu}-\mathrm{k}_{\alpha}$ radiation and a $\mathrm{Ni}$ filter. 


\section{RESULTS AND DISCUSSION}

The electrochemical behaviour of two copper-silver alloys was studied in $0.5 \mathrm{M} \mathrm{NaOH}$ containing $0.001 \mathrm{M}$ of $\mathrm{Na}_{2} \mathrm{~S}$ and the results are presented in Fig. 1. The electrochemical behaviour of pure copper and pure silver was included for comparison. All the following voltammograms were recorded in the first sweep. Figure 1a represents the electrochemical behaviour of polycrystalline silver [3] between the starting potential $\mathrm{E}_{\mathrm{c}}=-1600 \mathrm{mV}$ and the switching potential $\mathrm{E}_{\mathrm{a}}=800 \mathrm{mV}$ with a scan rate $50 \mathrm{mV}$ $\mathrm{s}^{-1}$ at $25^{\circ} \mathrm{C}$. The voltammogram was characterized by the appearance of five anodic peaks $\mathrm{A}_{1}, \mathrm{~A}_{3}, \mathrm{~A}_{7}$, $\mathrm{A}_{8}$ and $\mathrm{A}_{9}$ prior to the oxygen evolution reaction. The anodic peak $\mathrm{A}_{1}$ was attributed to the formation of $\mathrm{Ag}_{2} \mathrm{~S}$ on the electrode surface through reaction $1[3,4]$

$$
2 \mathrm{Ag}+\mathrm{S}^{2-} \rightarrow \mathrm{Ag}_{2} \mathrm{~S}+2 \mathrm{e}^{-}
$$

The formed $\mathrm{Ag}_{2} \mathrm{~S}$ layer was found to suffer of pitting attack $[3,5]$. The anodic peak $\mathrm{A}_{3}$ was attributed to the formation of $\mathrm{S}$, reaction $2[3,4]$ :

$$
\mathrm{S}^{2-} \rightarrow \mathrm{S}+2 \mathrm{e}^{-}
$$

The anodic peak $A_{7}$ was assigned to the dissolution of $\mathrm{Ag}$ to $\left[\mathrm{Ag}(\mathrm{OH})_{2}\right]^{-}$through adsorption of $\mathrm{OH}^{-}$ and desorption and diffusion of soluble $\left[\mathrm{Ag}(\mathrm{OH})_{2}\right]^{-}$as shown in reactions 3 and 4 [6, 7]:

$$
\begin{gathered}
\mathrm{Ag}+2 \mathrm{OH}^{-} \rightarrow\left[\mathrm{Ag}(\mathrm{OH})_{2}\right]^{-}{ }_{\text {ads }}+\mathrm{e}^{-} \\
{\left[\mathrm{Ag}(\mathrm{OH})_{2}\right]^{-}{ }_{\text {ads }} \rightarrow\left[\mathrm{Ag}(\mathrm{OH})_{2}\right]^{-}{ }_{\text {aq }}}
\end{gathered}
$$

The anodic peak $A_{8}$ was related to the formation of $\mathrm{Ag}_{2} \mathrm{O}$ through the following reaction 5 [8]:

$$
2 \mathrm{Ag}+2 \mathrm{OH}^{-} \rightarrow \mathrm{Ag}_{2} \mathrm{O}+\mathrm{H}_{2} \mathrm{O}+2 \mathrm{e}^{-}
$$

It has been suggested that the formation of $\mathrm{Ag}_{2} \mathrm{O}$ layer occurs via a nucleation and growth mechanism [8]. When the thickness of $\mathrm{Ag}_{2} \mathrm{O}$ exceeds a certain value, the current density decreases, indicating the onset of primary passivation. The appearance of the anodic peak $A_{9}$ was related to the oxidation of $\mathrm{Ag}_{2} \mathrm{O}$ to $\mathrm{AgO}[4,9]$ and the formation of soluble $\mathrm{SO}_{4}{ }^{2-}[10]$ compounds according to reactions 6 and 7:

$$
\begin{array}{cc}
\mathrm{Ag}_{2} \mathrm{O}+2 \mathrm{OH}^{-} \rightarrow 2 \mathrm{AgO}+\mathrm{H}_{2} \mathrm{O}+2 \mathrm{e}^{-} & {\left[\mathrm{A}_{9}\right]} \\
2 \mathrm{~S}^{2-}+7 / 2 \mathrm{O}_{2}+\mathrm{H}_{2} \mathrm{O} \rightarrow 2 \mathrm{SO}_{4}{ }^{2-}+2 \mathrm{H}^{+}+2 \mathrm{e}^{-} & {\left[\mathrm{A}_{9}\right]}
\end{array}
$$

Figure $1 \mathrm{~b}$, represents the potentiodynamic anodic polarization behaviour of pure copper in $0.5 \mathrm{M}$ $\mathrm{NaOH}$ containing $0.001 \mathrm{M}$ of $\mathrm{Na}_{2} \mathrm{~S}$ between the starting potential $\mathrm{E}_{\mathrm{c}}=-1600 \mathrm{mV}$ and the switching potential $\mathrm{E}_{\mathrm{a}}=800 \mathrm{mV}$ with a scan rate $50 \mathrm{mV} \mathrm{s}^{-1}$ at $25^{\circ} \mathrm{C}$. The anodic sweep of potential was 

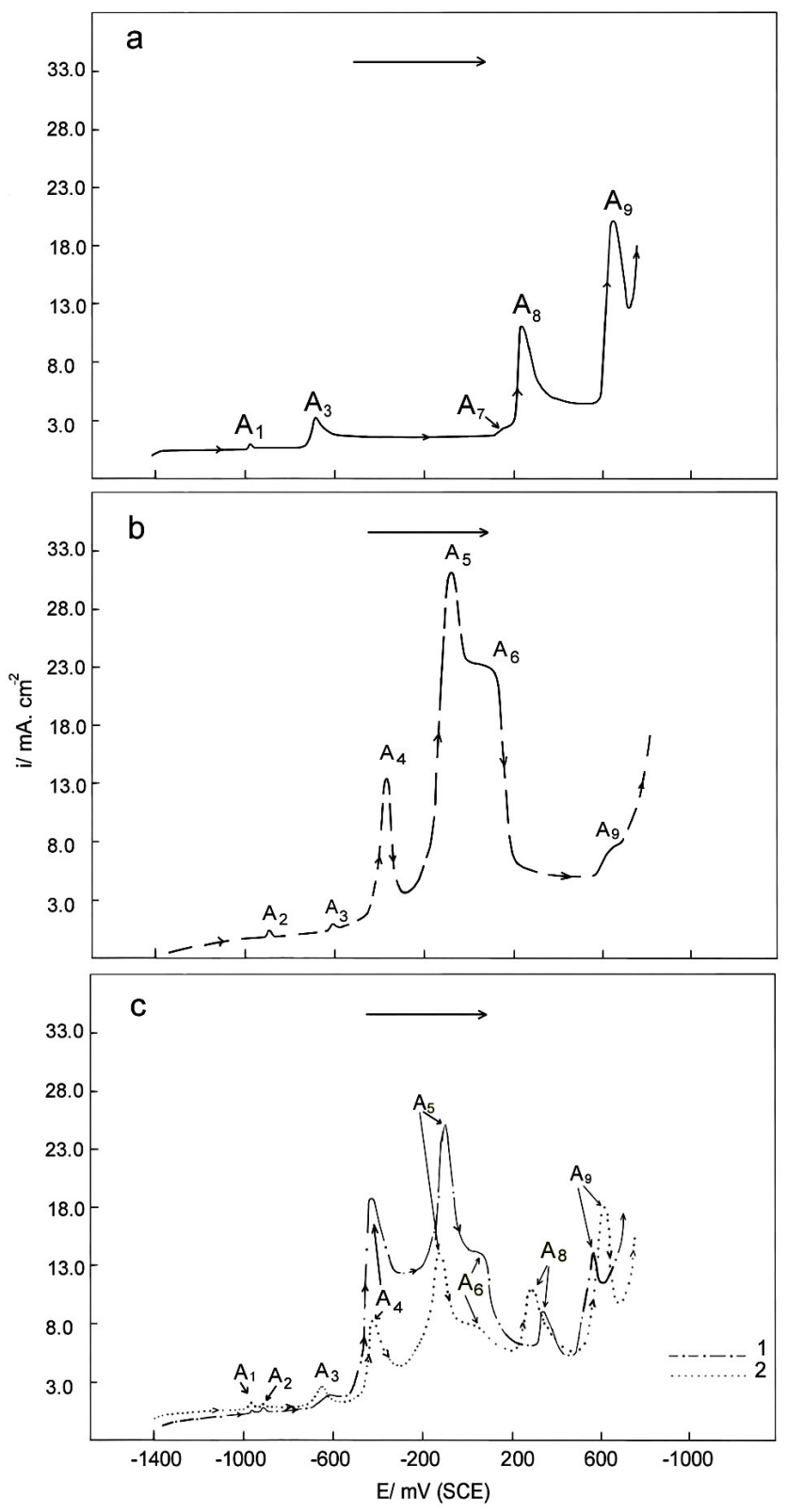

Figure 1. Cyclic voltammograms of (a) silver, (b) copper and (c) alloy I (curve 1) and alloy II (curve 2) in $0.5 \mathrm{M} \mathrm{NaOH}$ containing $0.001 \mathrm{M} \mathrm{Na}_{2} \mathrm{~S}$ at $25^{\circ} \mathrm{C}$ and scan rate $50 \mathrm{mV} \mathrm{s}^{-1}$.

associated with the appearance of five anodic peaks prior to the oxygen evolution reaction, namely, $\mathrm{A}_{2}$, $\mathrm{A}_{4}, \mathrm{~A}_{5}, \mathrm{~A}_{6}$ and $\mathrm{A}_{9}$. The appearance of the anodic peak $\mathrm{A}_{2}$ was due to the formation of $\mathrm{Cu}_{\mathrm{x}} \mathrm{S}$ [11] (where $\mathrm{x}=1$ or 2). The anodic peak $A_{4}$ was related to the formation of a porous layer of $\mathrm{Cu}_{2} \mathrm{O}$ via solid-state process [12] according to reaction 8:

$2 \mathrm{Cu}+2 \mathrm{OH}^{-} \rightarrow \mathrm{Cu}_{2} \mathrm{O}+\mathrm{H}_{2} \mathrm{O}+2 \mathrm{e}^{-}$ 
The preferable adsorption of $\mathrm{OH}^{-}$ions assisted the formation of $\mathrm{Cu}_{2} \mathrm{O}$ solid phase on the electrode surface. The surface of the metal now was covered with a layer of $\mathrm{Cu}_{2} \mathrm{O}$, which grew with a porous structure [12] and the metal dissolution as $\mathrm{Cu}^{2+}$ species occurred within the pores

$$
\mathrm{Cu}+\mathrm{n} \mathrm{OH}^{-} \rightarrow \mathrm{Cu}(\mathrm{OH})_{\mathrm{n}}^{2-\mathrm{n}}+2 \mathrm{e}^{-}
$$

Since the pores widen with time [12], some oxidative dissolution of $\mathrm{Cu}_{2} \mathrm{O}$ must also occur as in reaction 10 :

$$
\mathrm{Cu}_{2} \mathrm{O}+\mathrm{H}_{2} \mathrm{O}+(2 \mathrm{n}-2) \mathrm{OH}^{-} \rightarrow 2 \mathrm{Cu}(\mathrm{OH})_{\mathrm{n}}{ }^{2-\mathrm{n}}+2 \mathrm{e}^{-} \quad\left[A_{5}\right]
$$

When the potential exceeded the potential of peak $A_{5}$ and reached the potential of peak $A_{6}$ the current density rose again indicating the transformation of the base layer of $\mathrm{Cu}_{2} \mathrm{O}$ to $\mathrm{CuO}$. The cupric hydroxide, $\mathrm{Cu}(\mathrm{OH})_{2}$ filling the pores and overlaying $\mathrm{Cu}_{2} \mathrm{O}$ was converted to $\mathrm{CuO}$ since the latter is thermodynamically stable [13]. On further going to a more positive potential value the anodic peak $\mathrm{A}_{9}$ appeared as a result of the conversion of the sulphide ions to sulphate soluble compounds [10].

Figure 1c, curves 1 and 2 represent the linear anodic polarization for the two alloys I and II in 0.5 $\mathrm{M} \mathrm{NaOH}$ containing $0.001 \mathrm{M}$ of $\mathrm{Na}_{2} \mathrm{~S}$ between the starting potential $\mathrm{E}_{\mathrm{c}}=-1600 \mathrm{mV}$ and the switching potential $\mathrm{E}_{\mathrm{a}}=800 \mathrm{mV}$ with a scan rate $50 \mathrm{mVs}^{-1}$ at $25^{\circ} \mathrm{C}$. Inspection of the data in Fig. 1c reveals the anodic sweep was characterized by the appearance of sulphide attack potential region that characterized by the appearance of three anodic peaks $A_{1}, A_{2}$ and $A_{3}$. The anodic peaks $A_{1}$ and $A_{2}$ are related to the formation of $\mathrm{Ag}_{2} \mathrm{~S}$ [3,4] and $\mathrm{Cu}_{\mathrm{x}} \mathrm{S}$ [11], respectively. The formation of $\mathrm{Ag}_{2} \mathrm{~S}$ and $\mathrm{Cu}_{\mathrm{x}} \mathrm{S}$ was associated with the formation of pitting in the electrode surface as seen from the SEM micrograph in Fig. 2 obtained for the alloy I surface after polarization from the starting potential $E_{c}=-1500 \mathrm{mV}$ to $-850 \mathrm{mV}$ with scan rate $50 \mathrm{mV} \mathrm{s}^{-1}$. It seems that the peak current densities of the two peaks $\mathrm{A}_{1}$ and $\mathrm{A}_{2}$ of the two alloys were between those of the pure metals, silver and copper. The peak current density of the anodic peak $A_{2}$ was higher in the alloys than that of the pure copper due to the galvanic coupling effect. The anodic peak $A_{3}$ was attributed to the formation of $S$ (as seen from the SEM micrographs in Fig. 3 obtained for alloy I electrode anodically polarized from $-1500 \mathrm{mV}$ to $-600 \mathrm{mV}$ in $0.5 \mathrm{M} \mathrm{NaOH}$ containing $0.005 \mathrm{M} \mathrm{Na}_{2} \mathrm{~S}$ ) [5]. Inspection of data given in the voltammograms reveals that the peak current density, $\mathrm{i}_{\mathrm{p}}$, of the anodic peak $\mathrm{A}_{3}$ was decreased and its peak potential, $\mathrm{E}_{\mathrm{p}}$, was displaced towards more cathodic value on increasing the copper content in the alloys. On further sweep of the potential to more noble value the voltammograms exhibited two potential regions [2]; copper dissolution potential region and silver dissolution potential region. In the copper dissolution region, copper dissolved preferentially, which was associated by the appearance three anodic peaks $\mathrm{A}_{4}, \mathrm{~A}_{5}$ and $\mathrm{A}_{6}$. These anodic peaks could be attributed to the formation of $\mathrm{Cu}_{2} \mathrm{O}, \mathrm{Cu}(\mathrm{OH})_{2}$ and $\mathrm{CuO}$, respectively [12]. The peak current density, $i_{p}$, of the anodic peak A4 (alloy II) was higher than that of pure copper. Also, the peak potentials, $E_{p}$, of the anodic peaks $A_{4}, A_{5}$ and $A_{6}$ for the two alloys were displaced towards more cathodic values than those for pure copper. The displacement was increased as the content of silver in the alloy was increased. This behaviour of accelerating copper dissolution from the alloys could be attributed to the galvanic coupling effect between copper and silver [14-17]. 


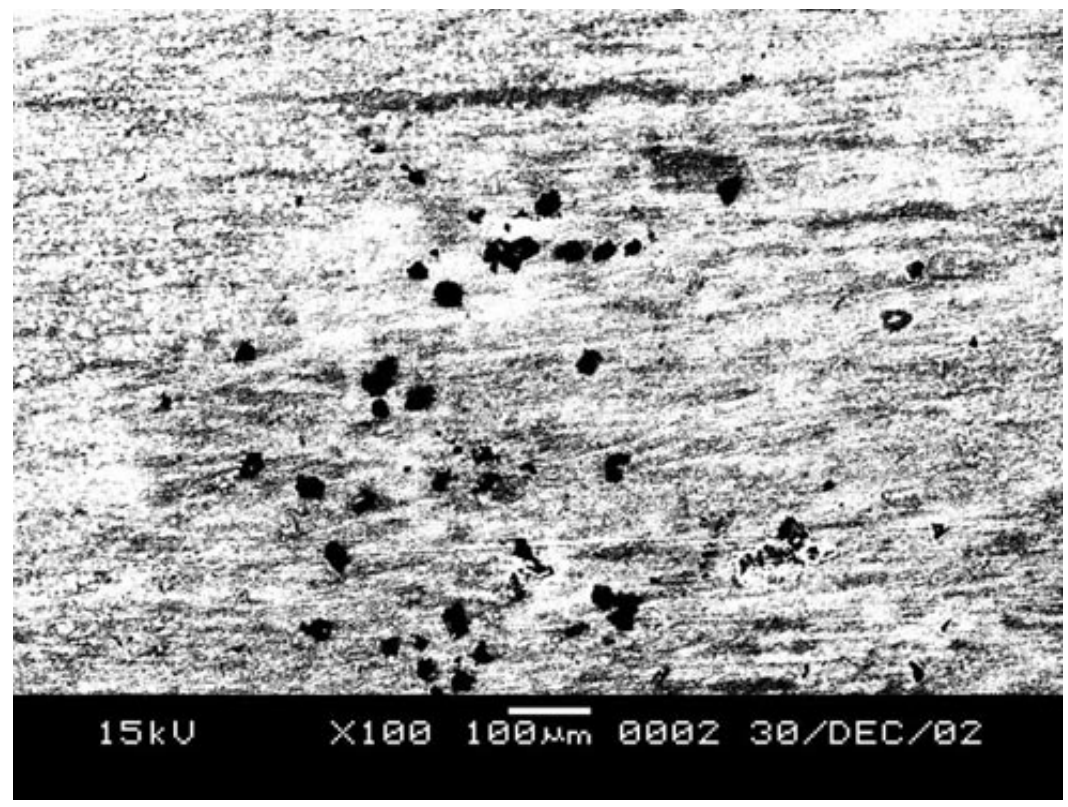

Figure 2. SEM micrographs (x100) of alloy $\mathrm{I}$ surface in $0.5 \mathrm{M} \mathrm{NaOH}$ containing $0.001 \mathrm{M} \mathrm{Na}_{2} \mathrm{~S}$ anodicaly polarized from the starting potential $\mathrm{E}_{\mathrm{c}}=-1500 \mathrm{mV}$ to $-850 \mathrm{mV}$ with scan rate $50 \mathrm{mV} \mathrm{s}^{-1}$ and at $25^{\circ} \mathrm{C}$.

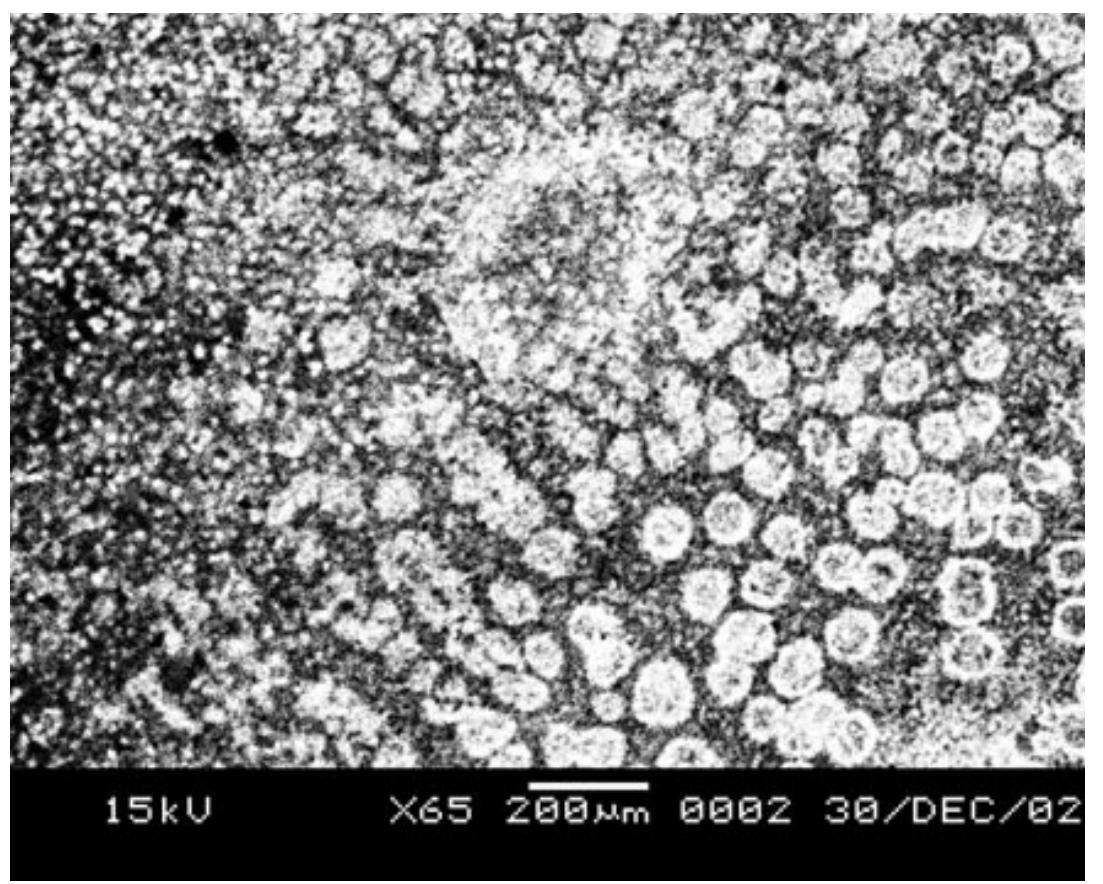

Figure 3. SEM (x65) micrographs of alloy I surface in $0.5 \mathrm{M} \mathrm{NaOH}$ containing $0.005 \mathrm{M} \mathrm{Na}_{2} \mathrm{~S}$ anodicaly polarized to $-600 \mathrm{mV}$ with scan rate $50 \mathrm{mV} \mathrm{s}^{-1}$ and at $25^{\circ} \mathrm{C}$.

Further sweep of the anodic potential to more positive values, the voltammogram showed the appearance of silver dissolution potential region. In this potential region silver started to dissolve. 
This potential region exhibited only two anodic peaks, namely, $A_{8}$ and $A_{9}$ followed by a rapid increase of the current as a result of the oxygen evolution reaction. The anodic peak $A_{8}$ was related to the formation of $\mathrm{Ag}_{2} \mathrm{O}$ [7]. The peak current density of the anodic peak $\mathrm{A}_{8}$ was decreased and its peak potential was shifted to less active value on increasing the copper content in the alloy. The anodic peak $\mathrm{A}_{9}$ was related to the oxidation of $\mathrm{Ag}_{2} \mathrm{O}$ to $\mathrm{AgO}[4,9]$ and the formation of soluble $\mathrm{SO}_{4}{ }^{2-}$ [10] compounds. The peak current density, $\mathrm{i}_{\mathrm{p}}$, of the anodic peak $\mathrm{A}_{9}$ was decreased and its peak potential, $\mathrm{E}_{\mathrm{p}}$, was shifted towards more active value as the copper content in the alloy was increased. X-ray diffraction analysis obtained for alloy I potentiodynamically polarized to $-550 \mathrm{mV}$ showed the existence of $\mathrm{Ag}_{2} \mathrm{~S}$ and $\mathrm{CuS}$ on the surface, Fig. 4. Also, Fig. 5, X-ray diffraction pattern, represents the existence of $\mathrm{Ag}_{2} \mathrm{~S}, \mathrm{CuS}, \mathrm{Ag}_{2} \mathrm{O}$ and $\mathrm{CuO}$ on the surface of alloy I potentiodynamically polarized to 400 $\mathrm{mV}$.

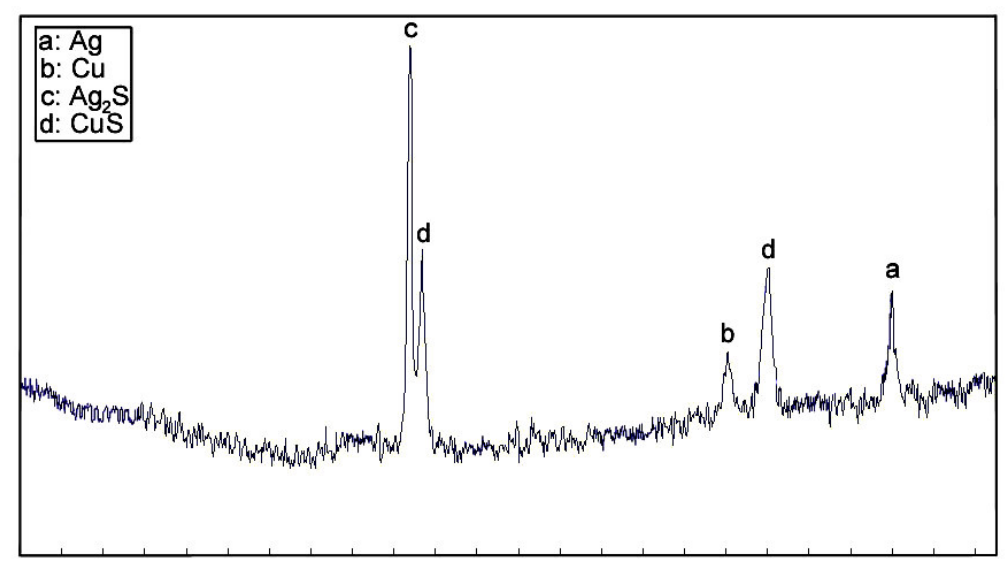

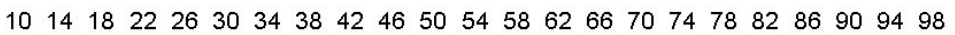

Figure 4. X-ray diffraction pattern of alloy I surface after anodic polarization to $-550 \mathrm{mV}$ in $0.5 \mathrm{M}$ $\mathrm{NaOH}$ that contains $0.001 \mathrm{M} \mathrm{Na}_{2} \mathrm{~S}$.

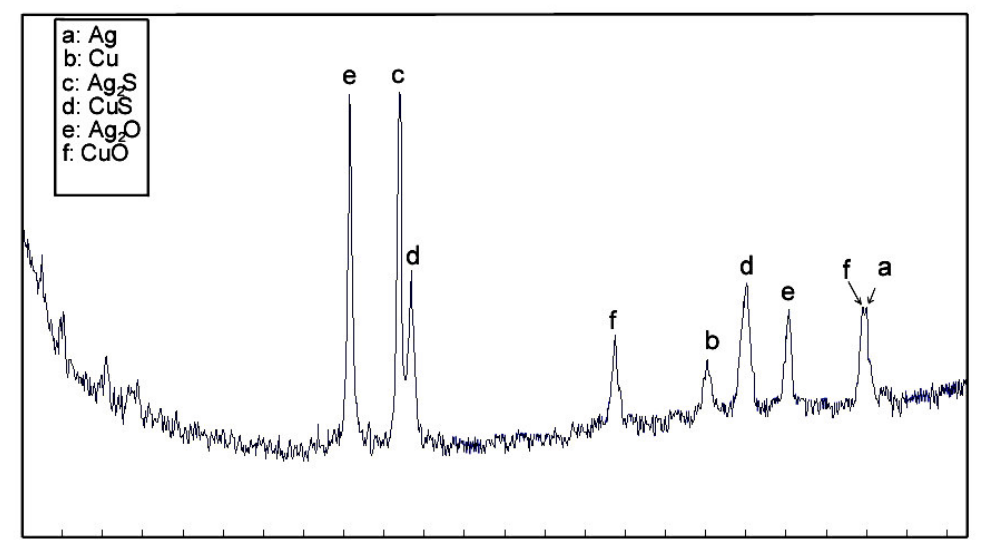

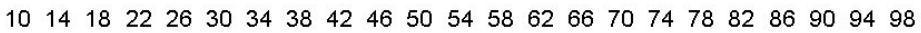

Figure 5. X-ray diffraction pattern of alloy I surface after anodic polarization to $400 \mathrm{mV}$ in $0.5 \mathrm{M}$ $\mathrm{NaOH}$ that contains $0.001 \mathrm{M} \mathrm{Na}_{2} \mathrm{~S}$. 


\subsection{Stepwise reversal potential}

The complementary relationship between the anodic and the cathodic peaks of alloy I in $0.5 \mathrm{M} \mathrm{NaOH}$ containing $0.001 \mathrm{M} \mathrm{Na}_{2} \mathrm{~S}$ was maintained by reversing the potential at different step potentials, $\mathrm{E}_{\mathrm{s}}$, at $25^{\circ} \mathrm{C}$ and scan rate $50 \mathrm{mV} \mathrm{s}^{-1}$, the data are represented in Fig. 6 . When $\mathrm{E}_{\mathrm{s}}$ was at value slightly more positive than that of the anodic peak $A_{1}$ only the cathodic peak $C_{1}$ appeared. This cathodic peak is probably in conjugation to the anodic peak $\mathrm{A}_{1}$ and could be attributed to the reduction of $\mathrm{Ag}_{2} \mathrm{~S}$ to $\mathrm{Ag}$. Reversal of the anodic potential at $\mathrm{E}_{\mathrm{s}}$ value more positive than that of the anodic peak $\mathrm{A}_{2}$ resulted in the appearance of two cathodic peaks $C_{1}$ and $C_{2}$. The cathodic peak $C_{2}$ is in conjugation to the anodic peak $A_{2}$ and may be related to the reduction of $\mathrm{Cu}_{\mathrm{x}} \mathrm{S}$ to $\mathrm{Cu}$. The cathodic peak $\mathrm{C}_{3}$ appeared when the anodic potential was reversed at $E_{s}$ value more noble than the anodic peak $A_{3}$, thus it is in conjugation with the anodic peak $A_{3}$ and could be related to the reduction of $S$ to sulphide ions. If $E_{s}$ was between the potential of the anodic peaks $\mathrm{A}_{4}$ and $\mathrm{A}_{5}$, four cathodic peaks $\mathrm{C}_{1}-\mathrm{C}_{4}$ appeared. It seems that the cathodic peak $\mathrm{C}_{4}$ is in conjugation to the anodic peak $\mathrm{A}_{4}$ and consequently could be related to the reduction of $\mathrm{Cu}_{2} \mathrm{O}$ to $\mathrm{Cu}$. However, five cathodic peaks $\mathrm{C}_{1}-\mathrm{C}_{5}$ were observed on reversing the anodic potential at $\mathrm{E}_{\mathrm{s}}$ value more noble than that of the anodic peak $\mathrm{A}_{5}$. Thus, the cathodic peak $\mathrm{C}_{5}$ is conjugated to the anodic peak $\mathrm{A}_{5}$ and may be related to the reduction of $\mathrm{Cu}(\mathrm{OH})_{2}$ to $\mathrm{Cu}$. Six cathodic peaks $\mathrm{C}_{1}-\mathrm{C}_{6}$ appeared on reversing the anodic potential $\mathrm{E}_{\mathrm{s}}$ in the potential region beyond the potential region of the anodic peak $\mathrm{A}_{6}$. The cathodic peak $\mathrm{C}_{6}$ is in conjugation to the anodic peak $\mathrm{A}_{6}$ and is ascribed to the reduction of $\mathrm{CuO}$ to $\mathrm{Cu}_{2} \mathrm{O}$. In the same way, the cathodic peaks $\mathrm{C}_{8}$ and $\mathrm{C}_{9}$ were recognized, in addition to the cathodic peaks $\mathrm{C}_{1}-\mathrm{C}_{6}$, as the step potential $\mathrm{E}_{\mathrm{s}}$ was at values nobler than those of the anodic peaks $A_{8}$ and $A_{9}$, respectively.

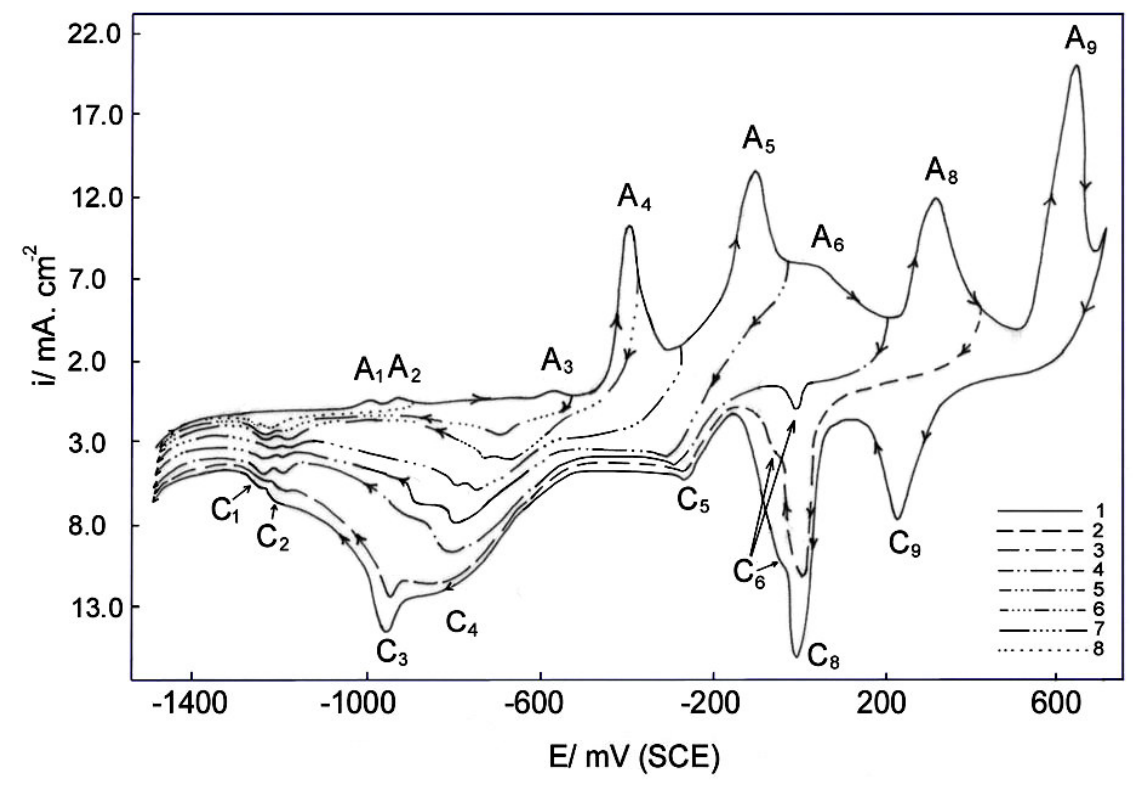

Figure 6. Cyclic voltammograms of alloy $\mathrm{I}$ in $0.5 \mathrm{M} \mathrm{NaOH}$ containing $0.001 \mathrm{M}$ of $\mathrm{Na}_{2} \mathrm{~S}$ at $25^{\circ} \mathrm{C}$, scan rate $50 \mathrm{mV} \mathrm{s}^{-1}$ and various reversing anodic potentials; (1) $730 \mathrm{mV}$, (2) $430 \mathrm{mV}$, (3) $200 \mathrm{mV}$, (4) -40 $\mathrm{mV}$ and (5) $-280 \mathrm{mV},(6)-380 \mathrm{mV},(7)-550 \mathrm{mV}$ and (8) $-900 \mathrm{mV}$. 


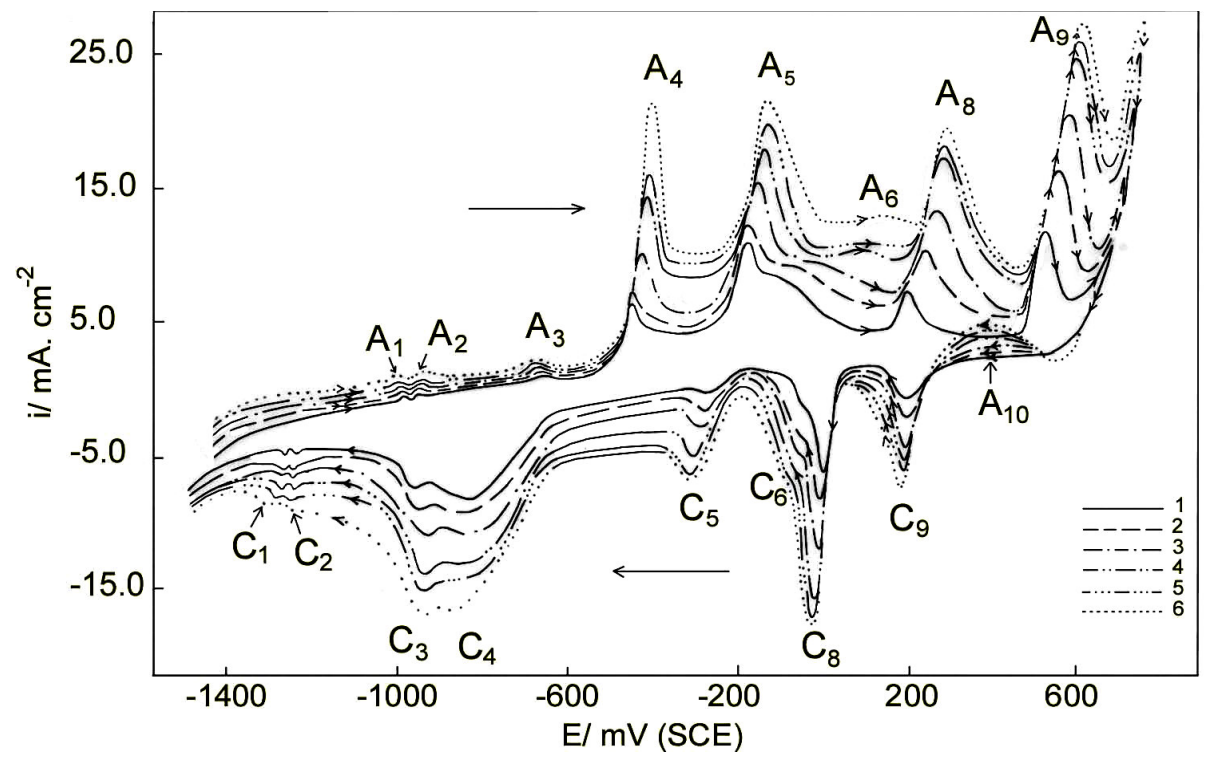

Figure 7. Cyclic voltammograms of alloy I in $0.5 \mathrm{M} \mathrm{NaOH}$ containing $0.001 \mathrm{M}$ of $\mathrm{Na}_{2} \mathrm{~S}$ at $25^{\circ} \mathrm{C}$ and different scan rates; (1) $10 \mathrm{mV} \mathrm{s}^{-1}$, (2) $25 \mathrm{mV} \mathrm{s}^{-1}$, (3) $50 \mathrm{mV} \mathrm{s}^{-1}$, (4) $75 \mathrm{mV} \mathrm{s}^{-1}$, (5) $100 \mathrm{mV} \mathrm{s}^{-1}$ and (6) $125 \mathrm{mV} \mathrm{s}^{-1}$.

Consequently, these two cathodic peaks are in conjugation to the anodic peaks $\mathrm{A}_{8}$ and $\mathrm{A}_{9}$, respectively. Consequently, the appearance of the cathodic peak $\mathrm{A}_{8}$ could be related to the reduction of $\mathrm{Ag}_{2} \mathrm{O}$ to $\mathrm{Ag}$. Also, the cathodic peak $A_{9}$ could be related to the reduction of $\operatorname{Ag}_{2} \mathrm{O}_{2}$ to $\operatorname{Ag}_{2} \mathrm{O}$.

\subsection{Effect of scan rate}

The effect of increasing scan rate on the electrochemical behaviour of alloy $\mathrm{I}$ in $0.5 \mathrm{M} \mathrm{NaOH}$ solution containing $0.001 \mathrm{M} \mathrm{Na}_{2} \mathrm{~S}$ were examined between $\mathrm{E}_{\mathrm{c}}=-1600 \mathrm{mV}$ and $\mathrm{E}_{\mathrm{a}}=800 \mathrm{mV}$ at $25^{\circ} \mathrm{C}$ and the data were represented in Fig. 7. Inspection of the data reveals that increasing scan rate increases the peak current density, $i_{p}$, of all the anodic and the cathodic peaks. The peak current density of the activation peak $A_{10}$ increased with increasing scan rate. At the same time, the peak potentials, $E_{p}$, of the anodic peaks $A_{2}, A_{4}, A_{5}, A_{6}, A_{8}$ and $A_{9}$ were shifted to more noble values whereas those of the anodic peaks $A_{1}$ and $A_{3}$ were shifted to more cathodic values with increasing scan rate. Also, increasing scan rate shifted the peak potentials, $\mathrm{E}_{\mathrm{p}}$, of all the cathodic peaks to more cathodic values. The relation between of the peak current density, $\mathrm{i}_{\mathrm{p}}$, of the same anodic peaks on the square root of scan rate, $v^{1 / 2}$, is presented graphically in Fig. 8. It is observed that some lines pass by the origin (for the anodic peaks $A_{4}, A_{5}, A_{8}$ and $A_{9}$. These results suggest that the processes associated with the appearance of these anodic peaks are under pure diffusion control. For diffusion control process the peak current density is related to the square root of the scan rate, $v^{1 / 2}$, via the following Randles-Sevcik $[18,19]$ equation: 


$$
\mathrm{i}_{\mathrm{p}}=\left(2.687 \times 10^{5}\right) \mathrm{n}^{3 / 2} v^{1 / 2} \mathrm{D}^{1 / 2} \mathrm{C}
$$

In this equation, $\mathrm{n}$ is the number of electrons appearing in half-reaction for the redox couple, $\mathrm{v}$ is the sweep rate, $\mathrm{C}, \mathrm{D}$ is the concentration and the diffusion coefficient of the diffusing species and the constant is understood to have units of $\mathrm{C} \mathrm{mol}^{-1} \mathrm{~V}^{-1 / 2}$ while the temperature is assumed to be $25^{\circ} \mathrm{C}$. The line for the anodic peak $\mathrm{A}_{6}$ does not pass by the origin which points to some kinetic control instead of pure diffusion control.

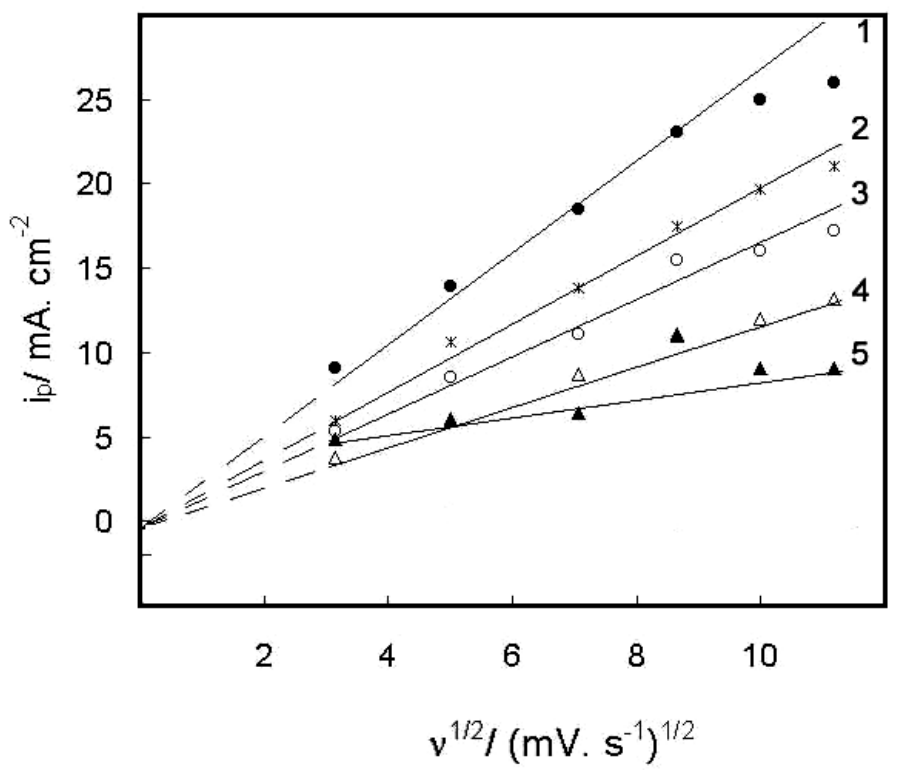

Figure 8. Relation between the peak current density, $i_{p}$, of the anodic peaks and the root of scan rate for alloy I: (1) $A_{9}$, (2) $A_{5}$, (3) $A_{8}$, (4) $A_{4}$ and (5) $A_{6}$.

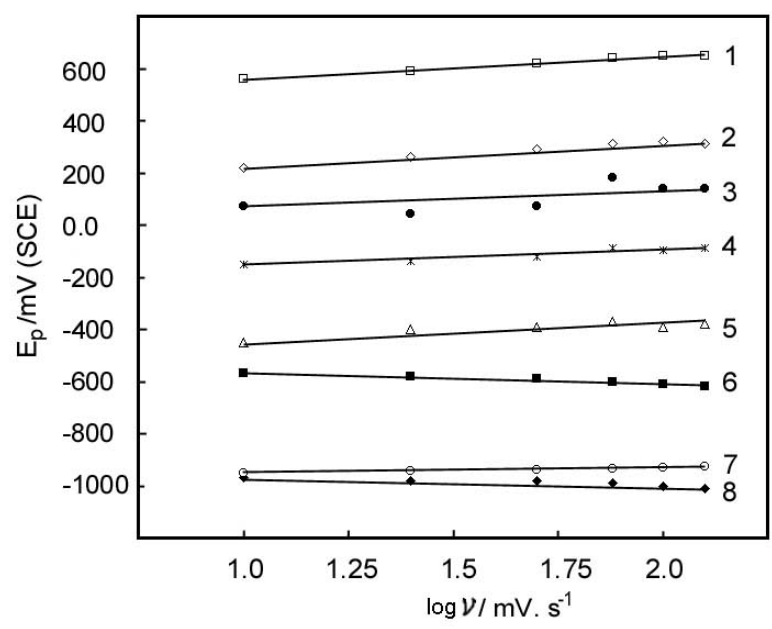

Figure 9. Linear dependence of the peak potential $E_{p}$ of the anodic peaks on log $v$ for alloy I; (1) $A_{9}$, (2) $\mathrm{A}_{8}$, , (3) $\mathrm{A}_{6}$, (4) $\mathrm{A}_{5}$, (5) $\mathrm{A}_{4}$, , (6) $\mathrm{A}_{3}$, (7) $\mathrm{A}_{2}$ and (7) $\mathrm{A}_{1}$. 


\subsection{Effect of sulphide concentration}

The effect of increasing sulphide ion concentration on the electrochemical behaviour of alloy I in 0.5 $\mathrm{M} \mathrm{NaOH}$ was studied between $\mathrm{E}_{\mathrm{c}}=-1600 \mathrm{mV}$ and $\mathrm{E}_{\mathrm{a}}=800 \mathrm{mV}$ at scan rate $50 \mathrm{mV} \mathrm{s}^{-1}$ and $25^{\circ} \mathrm{C}$, the data are shown in Fig. 9. Increasing the sulphide ion concentration increased the heights of all the anodic peaks. Increasing the peak current density of the anodic peaks $\mathrm{A}_{4}-\mathrm{A}_{8}$ could be attributed to the increase in the electrode surface area by increasing pitting formation. At the same time, the increase in the peak current density of the anodic peaks $A_{1}, A_{2}, A_{3}$ and $A_{9}$ is due to the increase in the reaction rate in the vicinity of these anodic peaks with increasing sulphide ion concentration.

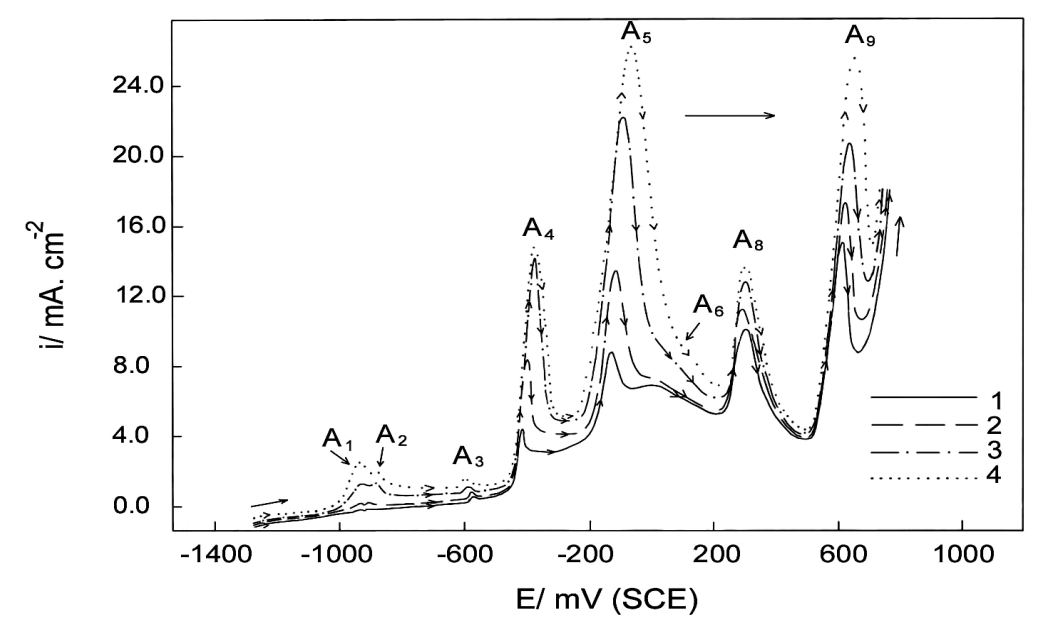

Figure 10. Cyclic voltammograms of alloy $\mathrm{I}$ in $0.5 \mathrm{M} \mathrm{NaOH}$ containing different concentrations of $\mathrm{Na}_{2} \mathrm{~S}$ at $25^{\circ} \mathrm{C}$ and scan rate $50 \mathrm{mV} \mathrm{s}^{-1}$; (1) $0.0005 \mathrm{M}$, (2) $0.001 \mathrm{M}$, (3) $0.003 \mathrm{M}$ and (4) $0.005 \mathrm{M}$.

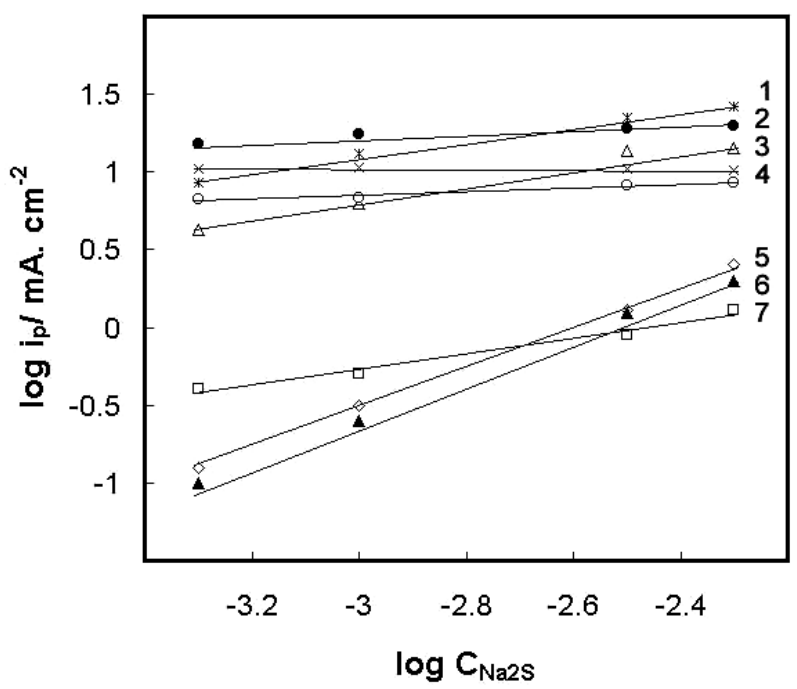

Figure 11. Relations between $\log i_{p}$, of the anodic peaks and $\log C_{\mathrm{Na} 2 \mathrm{~S}}$ for alloy I: (1) $A_{5}$, (2) $A_{9}$, (3) $A_{4}$, (4) $A_{8}$, (5) $A_{6}$, (6) $A_{1}$, (7) $A_{2}$ and (8) $A_{3}$. 
At the same way, increasing sulphide ion concentration shifted the peak potential, $\mathrm{E}_{\mathrm{p}}$, of the anodic peak $A_{1}$ towards more cathodic value. This shift could be understood in terms of the Nernst equation. The peak potential of the anodic peaks $\mathrm{A}_{2}, \mathrm{~A}_{3}, \mathrm{~A}_{4}, \mathrm{~A}_{5}, \mathrm{~A}_{6}, \mathrm{~A}_{8}$ and $\mathrm{A}_{9}$ were displaced towards more noble values with increasing the sulphide ion concentration in the solution. The linear dependence of $\log i_{p}$ of the anodic peaks vs. $\log \mathrm{C}_{\mathrm{Na} 2 \mathrm{~S}}$ of the anodic peaks is presented in Fig. 10.

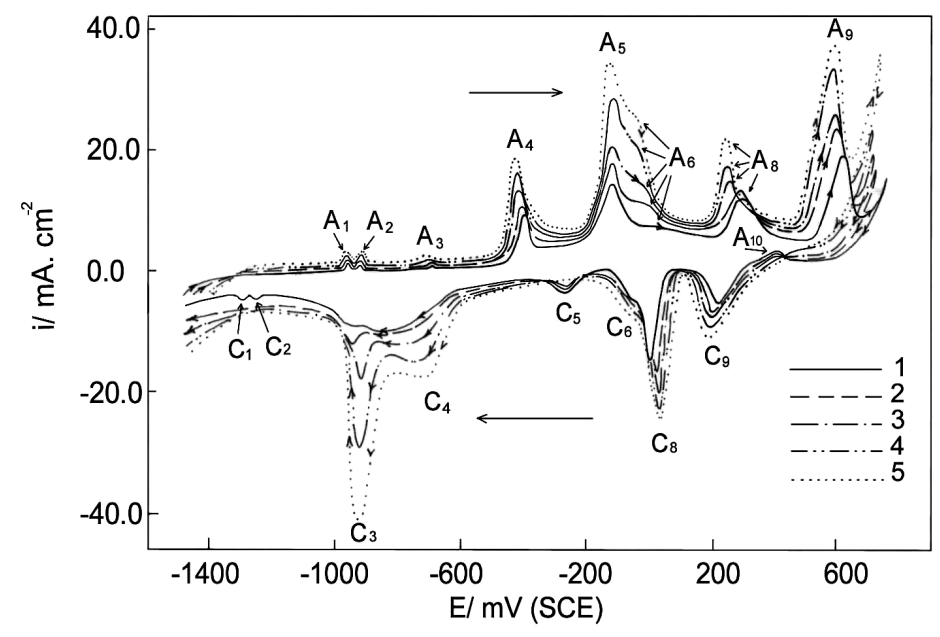

Figure 12. Cyclic voltammograms of alloy $\mathrm{I}$ in $0.5 \mathrm{M} \mathrm{NaOH}$ containing $0.001 \mathrm{M}$ of $\mathrm{Na}_{2} \mathrm{~S}$ at scan rate $50 \mathrm{mV} \mathrm{s}^{-1}$ and various temperatures; (1) $25^{\circ} \mathrm{C}$, (2) $30^{\circ} \mathrm{C}$, (3) $40^{\circ} \mathrm{C}$, (4) $50^{\circ} \mathrm{C}$ and (5) $60^{\circ} \mathrm{C}$.

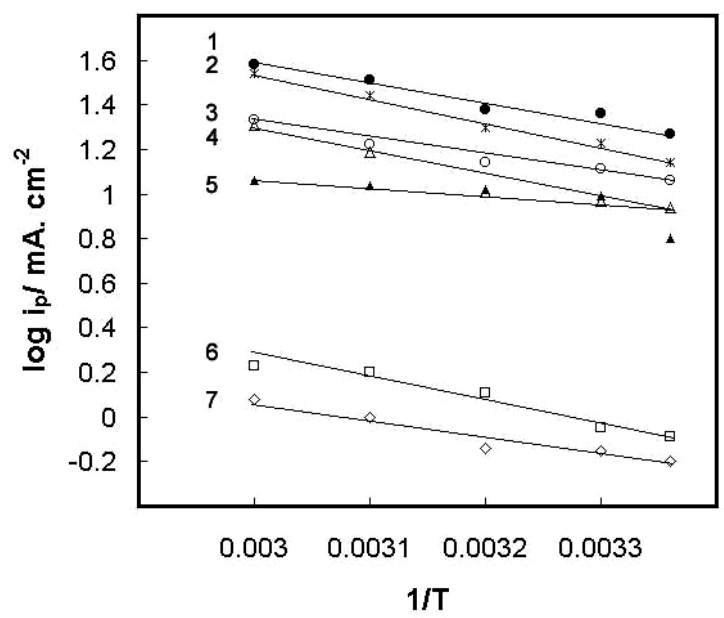

Figure 13. Linear dependence of the peak current density $i_{p}$ of the anodic peaks on $1 / T$; (1) $A_{8}$, (2) $A_{5}$, (3) $A_{7}$, (4) $A_{3}$, (5) $A_{6}$, (6) $A_{2}$ and (7) $A_{1}$.

\subsection{Effect of temperature}

The effect of increasing solution temperature on the electrochemical behaviour of alloy I was studied in $0.5 \mathrm{NaOH}$ containing $0.001 \mathrm{M} \mathrm{Na}_{2} \mathrm{~S}$ between $\mathrm{E}_{\mathrm{c}}=-1600 \mathrm{mV}$ and $\mathrm{E}_{\mathrm{a}}=800 \mathrm{mV}$ at scan rate $50 \mathrm{mV} \mathrm{s}^{-}$ ${ }^{1}$ and $25^{\circ} \mathrm{C}$, Fig. 11. Increasing the solution temperature was found to increase the peak current density 


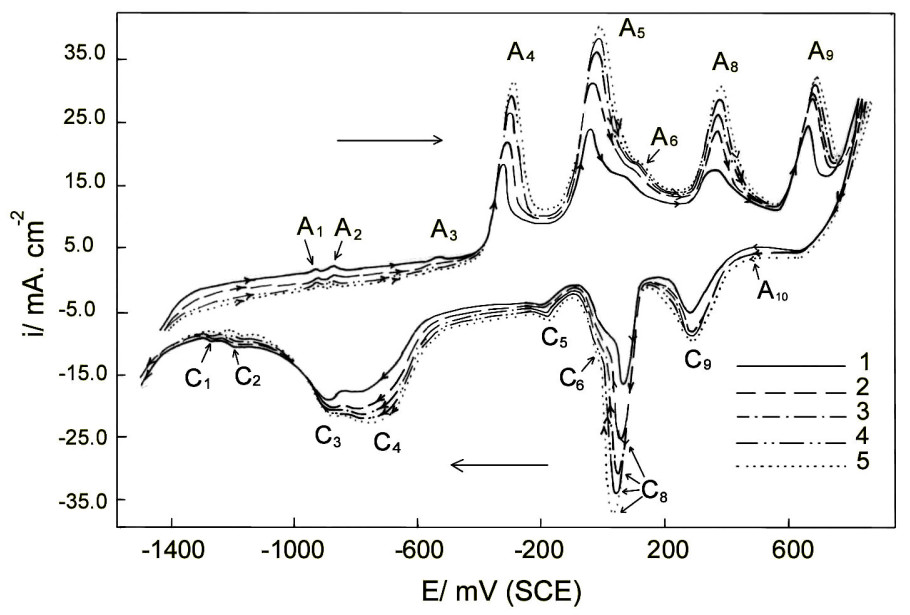

Figure 14. Cyclic voltammograms of alloy $\mathrm{I}$ in $0.5 \mathrm{M} \mathrm{NaOH}$ containing $0.001 \mathrm{M}$ of $\mathrm{Na}_{2} \mathrm{~S}$ at scan rate $50 \mathrm{mV} \mathrm{s}^{-1}, 25^{\circ} \mathrm{C}$ and different cycles; (1) cycle 1, (2) cycle 2, (3) cycle 3, (4) cycle 4 and (5) cycle 5.

of all the anodic peaks $\left(\mathrm{A}_{1}-\mathrm{A}_{9}\right)$ and shifted their peak potentials towards more active values. This behaviour could be attributed to the increase in the diffusion coefficient of the diffusive species with increasing the solution temperature where the diffusion coefficient is related to the peak current density via the Randles-Sevcik [18] equation:

$$
i_{p} \alpha D^{1 / 2}
$$

It is found that the logarithm of the peak current density $i_{p}$ of the cathodic peaks $C_{1}-C_{9}$ is a linear function with 1/T, following Arrhenius equation, as shown in Fig. 12:

$$
\log i_{p}=E_{a}^{o} / 2.303 R T+A
$$

Where $\mathrm{E}^{\mathrm{o}}$ is the apparent effective activation energy, $\mathrm{R}$ the ideal gas constant and $\mathrm{A}$ the Arrhenius preexponential factor. The Arrhenius plot for $\mathrm{I}_{\mathrm{pA}}$ furnishes apparent activation energy value $\mathrm{E}_{\mathrm{a}}^{\mathrm{o}}$ for electrochemical process associated with peak $A$ of $E^{*} \cong 6-19 \mathrm{k} \mathrm{J} \mathrm{mol}^{-1}$.

\subsection{Effect of cycling}

Figure 13 represents the effect of increasing the number of repeated cycles on the electrochemical behaviour of alloy I in the same solution, $0.5 \mathrm{M} \mathrm{NaOH}$ containing $0.001 \mathrm{M} \mathrm{Na}_{2} \mathrm{~S}$, at scan rate $50 \mathrm{mV} \mathrm{s}^{-}$

${ }^{1}$ and $25^{\circ} \mathrm{C}$. Repetitive cycling has no significant effect on the general trend of the cyclic voltammogram. It is seen that, the peak current densities of the anodic peaks $A_{1}, A_{2}, A_{3}, A_{4}, A_{5}, A_{6}, A_{8}$ and $\mathrm{A}_{9}$ and the cathodic peaks $\mathrm{C}_{1}, \mathrm{C}_{2}, \mathrm{C}_{3}, \mathrm{C}_{4}, \mathrm{C}_{5}, \mathrm{C}_{6}, \mathrm{C}_{8}$ and $\mathrm{C}_{9}$ tended to be enhanced slightly with increasing the number of the repeated cycles. The potential of the anodic peaks $A_{1}, A_{2}$ and $A_{3}$ was shifted to more active value whereas that of the cathodic peaks $\mathrm{C}_{3}, \mathrm{C}_{4}, \mathrm{C}_{5}$ and $\mathrm{C}_{9}$ was shifted to more 
noble value with repetitive cycling. This behaviour can be due to an activation of some electrode processes by cyclic polarization.

\section{CONCLUSION}

1. The anodic polarization response was characterized by the appearance of three potential regions: sulphide attack potential region, selective copper dissolution potential region and silver dissolution potential region, prior to the oxygen evolution reaction.

2. The first potential region was characterized by the appearance of three anodic peaks, i. e. $A_{1}$, $\mathrm{A}_{2}$ and $\mathrm{A}_{3}$ are related to the formation of $\mathrm{Ag}_{2} \mathrm{~S}, \mathrm{CuS}$ and sulphur on the electrode surface.

3. The formation of $\mathrm{Ag}_{2} \mathrm{~S}$ and $\mathrm{CuS}$ was associated by the formation of pits on the electrode surface. The existence of pits on the anode surface was confirmed by scanning electron microscope.

4. In the selective copper dissolution potential region, copper dissolution was associated with the appearance of three anodic peaks $\mathrm{A}_{4}, \mathrm{~A}_{5}$ and $\mathrm{A}_{6}$, which are related to the formation of $\mathrm{Cu}_{2} \mathrm{O}$, $\mathrm{Cu}(\mathrm{OH})_{2}$ and $\mathrm{CuO}$, respectively.

5. In the silver dissolution potential region, silver dissolution exhibits two anodic peaks $\mathrm{A}_{8}$ and $\mathrm{A}_{9}$, which are related to the formation of $\mathrm{Ag}_{2} \mathrm{O}$ and both of $\mathrm{AgO}$ and soluble $\mathrm{SO}_{4}{ }^{2-}$ compounds, respectively.

6. X-ray diffraction analysis confirmed the existence of $\mathrm{Ag}_{2} \mathrm{~S}, \mathrm{CuS}, \mathrm{Ag}_{2} \mathrm{O}$ and $\mathrm{CuO}$ on alloy I potentiodynamically polarized to $400 \mathrm{mV}$.

7. The formation of $\mathrm{CuS}, \mathrm{S}, \mathrm{Cu}_{2} \mathrm{O}, \mathrm{Cu}(\mathrm{OH})_{2}, \mathrm{CuO}$ and $\mathrm{Ag}_{2} \mathrm{O}$ are at least partially under diffusion control.

8. The reverse sweep was characterized by the appearance of one activation peak $\mathrm{A}_{10}$ and eight cathodic peaks $\mathrm{C}_{1}, \mathrm{C}_{2}, \mathrm{C}_{3}, \mathrm{C}_{4}, \mathrm{C}_{5}, \mathrm{C}_{6}, \mathrm{C}_{8}$, and $\mathrm{C}_{9}$. the cathodic peaks are related to the reduction of $\mathrm{Ag}_{2} \mathrm{~S}$ to $\mathrm{Ag}, \mathrm{CuS}$ to $\mathrm{Cu}, \mathrm{S}$ to $\mathrm{S}_{2}{ }^{-}, \mathrm{Cu}_{2} \mathrm{O}$ to $\mathrm{Cu}, \mathrm{Cu}(\mathrm{OH})_{2}$ to $\mathrm{Cu}_{2} \mathrm{O}, \mathrm{CuO}$ to $\mathrm{Cu}_{2} \mathrm{O}, \mathrm{Ag}_{2} \mathrm{O}$ to $\mathrm{Ag}$ and the reduction of $\mathrm{AgO}$ and to $\mathrm{Ag}_{2} \mathrm{O}, \mathrm{Ag}_{2} \mathrm{O}$ to $\mathrm{Ag}$ and soluble $\mathrm{SO}_{4}{ }^{2-}$ to $\mathrm{S}^{2-}$, respectively.

\section{References}

1. R. Lein, G. Bär, Elektrie, 33, No. 10 (1979) 511.

2. F. H. Assaf, A. M. Zaky and S. S. Abd El Rehim, 2002, Appl. surf. Sci. 187, no. 1-2, (2002) 18.

3. A. M. Zaky, F. H. Assaf, S. S. Abd El Rehim and B. M. Mohamed, Corros. Eng., Sci. and Technol. 40 (1) (2005) 21.

4. D. R. Lide and H. P. R. Frederikse, Handbook of Chemistry and Physics, $75^{\text {th }}$ edition, Chemical / Rubber Publishing Co. (CRC), USA (1994).

5. N. J. Radic, K. J. Mulligan and Jr. H. B. Marc, Anal. Chem. 56 (1984) 297.

6. P. Stonhart, Electrochim. Acta 13 (1968) 1789.

7. R. D. Giles and J. A. Harrison, J. Electroanal. Chem. 27 (1970) 161.

8. G. W. Briggs, M. Fleischmann, D. J. Lax and H. R. Thirsk, Trans. Faraday Soc. 64 (1968) 3120. 
9. R. S. Perkins, B. W. Tilak, B. E. Conway and H. A. Kozlowska, Electrochim. Acta 17 (1972) 1471.

10. R. B. Herbert Jr., Sulphide Oxidation in Mine Waste Deposits, MiMi print, ISSN 14039478, S- 10691 Stockholm, Sweden (1999).

11. N. R. de Tacconi, K. Rajeshwar and R. O. Lezna, J. Phys. Chem. 100 (1996) 18234.

12. N. S. McIntyre, S. Sunder, D. W. Shoesmith and F. W. Stanchell, J. Vac. Sci. Tech. 18 (1981) 714.

13. D. W. Shoesmith, S. Sunder, M. G. Bailey, G. J. Wallace and F. W. Stanchell, J. Electroanal. Chem. 143 (1983) 153.

14. Y. U. Choi , E. C. Lee and K. N. Han, Metall. Trans. B 22B (1991) 755.

15. L. L. Tokar, T. A. Taritsyna, Y. S. Sorikov, M. S. Igumnov, S. A. Erofeev and C. D. Men'shikov, Zhurnal Prikladnoi Khimii, 63 (1990) 2638.

16. Y. C. Guan and K. N. Han, Mineral Metall. Processing (1994) 12.

17. Y. C. Guan and K. N. Han, J. Electrochem. Soc., 142 (1995) 1819.

18. J.E.B. Randles, Trans. Faraday Soc. 44 (1948) 327.

19. A. Sevcik, Collect Czech Chem. Commun. 13 (1948) 349.

(C) 2006 by ESG (www.electrochemsci.org) 